\title{
sciendo
}

DOI: $10.2478 /$ abcsj-2019-0015

American, British and Canadian Studies, Volume 33, December 2019

Kitchen and Other Tables to Think With:

The Case of To the Lighthouse, The Cook, the Thief, His Wife

and Her Lover and In the Mood for Love

\author{
ESTELLA ANTOANETA CIOBANU \\ Ovidius University of Constanţa, Romania
}

\begin{abstract}
This article studies comparatively references to tables in Virginia Woolf's novel To the Lighthouse and two films, Peter Greenaway's The Cook, the Thief, His Wife and Her Lover and Wong Kar-Wai's In the Mood for Love. Greenaway announces from the title a concern with a cook, which the film duly elaborates by setting its action mostly in a restaurant and its kitchen; tables as the central part of the set visualise power configurations. In Wong's film about failed love, the kitchen and/or tables as part of the décor reinforce mainstream notions of middle-class domesticity. Woolf challenges middle-class views of gender in two episodes from Part I - Mrs Ramsay's dinner party and the dialogue between Lily Briscoe and Andrew Ramsay about the object of his father's philosophy books - by defamiliarising respectively the dining- and kitchen tables. The latter scene, which repurposes the idea of the kitchen table as an analogon for philosophy's construal of the nature of reality, opens up an epistemic avenue: thinking with the kitchen table. My general frame for analysis is Edmund Husserl's concept of orientation, sustained by Bertrand Russell's propositions about unobserved objects and unoccupied perspectives. However, I twist these conceptual tools intersectionally to unravel the social grounds of philosophical and artistic positions that obfuscate gendered contributions to knowledge, sustenance and general well-being.
\end{abstract}

Keywords: To the Lighthouse (Virginia Woolf), The Cook, the Thief, His Wife and Her Lover (Peter Greenaway), In the Mood for Love (Wong KarWai), kitchen table, dinner table, intersectionality theory, philosophy, orientation (Edmund Husserl), unobserved objects (Bertrand Russell), unoccupied perspective (Bertrand Russell) 
I can let my attention wander away from the writing table which was just now seen and noticed out through the unseen parts of the room which are behind my back, to the verandah, into the garden, to the children in the arbor, etc. ... (Husserl 51-2)

Not a poet has penned the above sentence, but Edmund Husserl, not in a diary entry, but in the first volume of his Ideas, not to contemplate those elements in themselves, i.e., for what they are worth to one emotionally, aesthetically and so on, but as cognitive pegs. Husserl deploys the "objects" around him, whether perceived or intuited, inanimate or animate (and human), to demonstrate his phenomenological thesis about orientation: the world unfolds from oneself as centre of experience through the working of intentional consciousness (i.e., the consciousness of something).

This article draws on Husserl's concept of orientation to study comparatively references to tables in Virginia Woolf's 1927 novel To the Lighthouse (henceforth TL), Peter Greenaway's 1989 film The Cook, the Thief, His Wife and Her Lover (CTWL) and Wong Kar-Wai's 2000 film In the Mood for Love $(M L) .{ }^{1}$ The first sense of table in the Oxford Dictionary online concerns "a piece of furniture with a flat top and one or more legs, providing a level surface for eating, writing, or working at"; the word's lexical scope includes synecdochically "food provided in a restaurant or household" and "a group seated at table for a meal" ("Table"). Setting aside for now the western history of this piece of furniture in connection with food and those who eat it, let alone with other activities such as writing, I examine here the most mundane situation involving tables: their use for eating and/or cooking. A convenient set for such everyday activities, the table, however, functions in the social context as a signifier in a second-degree cultural sign, sometimes with unexpected results.

What follows uses intersectional theory as an interpretive framework. I apply Husserl's concept of orientation, itself reappraised intersectionally, to the three works' references to the table in relation to the two genders, first separately and then together. The order in which I address the genders examines how the table works to support or resist men's power under patriarchy. 
To See or Not to See: Philosophical Orientations

The concept of orientation first commanded my attention thanks to Sara Ahmed's (151-4) apt reading of Husserl's philosophic scape as experientially grounded in his writing table - and, at another level, the chair of philosophy, secured through his public recognition. Husserl's orientation crucially depends on his social and biological inheritance (Ahmed 154):

By reading the objects that appear in Husserl's writing, we get a sense of how being directed towards some objects and not others involves a more general orientation towards the world. The direction you face is not simply casual: the fact that Husserl faces the writing table is a sign of his occupation. So Husserl's gaze might fall on the paper, which is on the table, given that he is sitting at the desk, the writing table, and not at another kind of table, such as the kitchen table. Such other tables would not, perhaps, be the "right" kind of tables for the making of philosophy. The writing table might be the table "for him," the one that would provide the right kind of horizontal surface for the philosopher. (Ahmed 151-2, emphasis added)

A philosopher's place is in his (sic) study, Husserl suggests. He would be out of place in the kitchen, Ahmed wryly implies. (Picture Husserl seated at the kitchen table to make philosophy!) Let's read Ahmed's inheritance in intersectional terms. Maleness, in a patriarchal world, and middle class, in its kyriarchal organisation, ${ }^{2}$ intersect ${ }^{3}$ to entitle some individuals, like Husserl himself, but not others, like his children's nanny, to the education, money and leisure necessary to contemplate the world philosophically and become influential and/or remembered.

Examining what is around a male phenomenologist, in terms of both objects and habitat-cum-habitus, may illuminate what cannot be (acknowledged as being) there. Husserl's line of philosophising draws attention to the "natural world" of - paradoxically, value-laden - objects as perceptible "in the natural attitude" (Husserl 54). ${ }^{4}$ Should the philosopher confine himself (sic) in his study or library (all alone), or can he be located spatially elsewhere too? Can he pursue his object of enquiry, solitary, though not alone, in the reading room of a public library? Alone on a meadow or the river bank? At a picnic on the same? In the company of others in the dining room (or drawing room or parlour), in the café or in 
a crowded square? In the kitchen amidst cooking utensils? In the nursery? Husserl is no Theophrastus; his phenomenology still has his children at the back of his mind, or rather has them silently recede into the background of his consciousness (Husserl 52) - where he entertains them as mere props, mnemonic pegs, or rather philosophical brainchildren, here propositions about orientation. Nonetheless, the children are at a safe acoustic and cognitive distance from their philosopher father, in a philosophical both-afar-and-yet-on-hand game, the philosopher's fort-da game. Only the philosophical table is right on hand, present and readily available (because at hand, close by), yet also in need of phenomenological reappraisal.

The one and only place for the male philosopher to be able to gaze at the world, therefore, is at his writing table - staunch, undemanding and severed from noisy activities, supportive of books and metonymically of ideas. Regarded bottom up, the orientation Husserl chooses is symptomatic, I suggest, of the silent en-gendering, i.e., gendered production, ${ }^{5}$ of philosophical pursuits and methodology against the backdrop of the kyriarchal polity. Upper-class and upper-middle-class white men philosophise, with or without the writing table, and generally rule the polity, whereas women of similar standing and race supervise (or assess) the laying and decoration of the dining table, as Woolf's Mrs Ramsay does, or tend to the well-being and virtuous lives of their family. It is left to lower-class white or non-white men and women to act as domestics in the service of and suppliers to the former gender-divided group in order to ensure the sustenance and good functioning of the upperor middle-class domestic haven and of the polity alike. Yet, as intersectionality and subaltern theorists argue, these subalterns are traditionally rendered immaterial - invisible and silenced. My analysis will hopefully contribute to a better understanding of such intersectional silencing by thinking with the table.

\section{Men and/at the Table}

Publicly, the dining table, in $T L$, provides the physical setting for and focus of the dinner party, and metaphorically the catalyst for conversation and appetite alike. Privately, however, both the hostess and some of her 
guests realise they are divided, whether by social allegiances, incommensurate sensibilities or a discrepancy between how they feel and what they do.

For William Bankes, the elderly botanist, or Charles Tansley, the young aspiring philosopher, not so much the dining table as the commensal occasion becomes an emotional - transcoded as professional trial. Both men hurt that (middle-class) civility, especially commensality, detracts them from their professional pursuits (Woolf 241-5). Tansley deplores men's succumbing to women's nefarious lure:

For he [Tansley] was not going to talk the sort of rot these people wanted him to talk. He was not going to be condescended to by these silly women.... They made men say that sort of things.... They did nothing but talk, talk, talk, eat, eat, eat. It was the women's fault. Women made civilisation impossible with all their "charm," all their silliness. (Woolf 242)

Tansley's misogyny nurses socially untenable arguments: female-driven frivolity boosted by such parties impedes the very progress of civilisation. (Tansley might regard himself as an imperilled contributor to progress.)

Both men, accordingly, need a physical table and the commensality it fosters to lay their resentment against women on, if quietly (viz., realised textually as free indirect thought). They conveniently ignore, though, that such occasions (both ritual or festive and everyday), whether or not signalled by a table, were invented - by men, not by women - to establish social bonds, as Georg Simmel argues, and generally as a "total social fact" that affords multiple intercourse (economic, jural, political, religious, aesthetic, moral), according to Marcel Mauss, in a power nexus of (partial or total) inclusion-exclusion, according to Foucault. ${ }^{6}$ Tansley, in particular, ignores that the ancient male Greeks turned commensalityoccasioned homoeroticism into a frivolous platform for philosophising; the not yet present dining table grounded - through the occasion's convivial commensality - the philosophical orientation of some of the participants as a function of their sexual orientation. ${ }^{7}$ The dining table causes Tansley's philosophical dis-orientation: the socially inept, classhostile junior philosopher feels torn between utter contempt especially for the women around the table and a desire to be able to talk kindly to fellow 
guests (Woolf 243), despite the mockery he suspects Lily of (242-3). The dining table reminds Bankes and Tansley that they have social obligations - ironically, concerning middle-class civility rather than lower-class or feminised domestic work for everyone else's sustenance.

If Woolf shows the characters seated around the table divided, Greenaway goes a step further, divided as CTWL is between tables that act as signifiers, as it is between showing and concealing, cooking gourmet dishes and cannibal feasts, witnessing legitimate, if violent, and illegitimate, if fulfilling, sex. ${ }^{8}$ In Albert Spica's Le Hollandais, the restaurant dining table figures power; unlike it, the kitchen tables disfigure power by either liquefying it (through Georgina's love affair) or by disseminating it (through the kitchen team work). I use the singular for the former type not primarily because Spica (Michael Gambon) says calmly, "This table should look the most important table in the room" (CTWL 00:17:25-00:17:28), whilst ordering (even roaring at) the waiters how to organise his table as the centre of power. Rather, the world of the restaurant and of Spica the gangster as faux socialite visibly and sonorously unfolds from his quasi-dais table, the point zero of orientation through restaurant commandeering and conspicuous consumption. What proceeds from thence is Spica's bully power in its homogenising drive to configure stable hierarchical polarities: the patrons (typically Spica himself) vs the staff $(00: 16: 59-00: 17: 25)$; the husband vs the wife (00:20:57-00:21:00, 00:36:44-00:37:54, 00:55:47-00:55:57); and the gangster vs non-peers, whether associates $(00: 20: 15-00: 20: 19,00: 39: 40$ 00:40:00, 00:58:51-00:58:59, 01:12:44-01:12:58, 01:36:52-01:37:54), kitchen staff $(00: 34: 23-00: 34: 57,01: 15: 41-01: 15: 52)$ or restaurant patrons (00:36:38-00:36:43, 00:49:45-00:50:46, 01:05:53-01:07:28, 01:13:3201:13:35, 01:13:39-01:14:14).

Contrariwise, the Le Hollandais kitchen tables signify heterogeneity as coincidentia oppositorum, for all activities aim at the preparation of meals (CTWL 00:06:00-00:07:23, 00:12:35-00:13:12, 00:32:18-00:33:08, $00: 45: 32-00: 46: 21)$ and satisfaction of patrons. These tables too participate in a hierarchy, albeit one which does not appear rigid and oppressive as that proceeding from Spica's dining table. ${ }^{9}$ Chef Richard Boarst's kitchen impresses through its baroque operational opulence and 
décor-enabled theatricality $(00: 06: 24-00: 10: 15),{ }^{10}$ rather than through its explicit power structures. Furthermore, as Richard (Richard Bohringer) accommodates adulterous sex in his kitchen, some of the place's topography, let alone use, is thoroughly defamiliarised. The pantry as the lovers' hothouse (00:33:13-00:33:20, 00:44:51-00:45:26, 00:59:4601:02:22, 01:04:28-01:04:51, 01:07:44-01:07:59, 01:10:01-01:10:36) and the freezer room as their temporary shelter $(01: 14: 59-01: 15: 16)$ against Spica when he storms the kitchen looking for his wife, Georgina (Helen Mirren), and her lover, Michael (Alan Howard), are alienating alcoves as well as curtained theatrical spaces (01:42:34-01:43:00). ${ }^{11}$ Not only do both the abused woman turned adulterous spouse and the hectored chef challenge and undermine Spica's tyrannical power precisely in the heterotopic kitchen; by thwarting Spica's illusion of total control over people, they also actively demonstrate that power-over can be trampled upon, however temporarily. Perhaps the phrase power flow - coterminous with the passageway kitchen topography - better describes Richard's kitchen than power structures does. Greenaway's plain tables in a not so plain kitchen layout can playfully (if vindictively) upturn the strictly patriarchal dining-table order of things.

Nor are Wong's tables any less divided, concerned as his film is with food-related conviviality within a group of Shanghainese refugees in British Hong Kong in 1962. ${ }^{12}$ Unlike in Greenaway, here not the abusive husband but the congenial wife and landlady, Mrs Suen (Rebecca Pan), offers the orientation, and the world unfolds as if a Chinese game of mahjong. The dining table enjoys pride of place, if typically vicariously: it's the people (ML 00:04:43-00:04:59) around the table - the Suens, the Koos and their tenants (among whom the Chans and the Chows) - that the camera focuses on, on and off, or rather their conversation and eating or game-playing activities. Only on one occasion does the dining table become visible (as a makeshift fundament): Mrs Koo demonstrates to her husband and neighbours how Mrs Chan's Japanese rice cooker operates (00:09:23-00:10:34).

By contrast, the camera focuses on restaurant tables. One scene occurs in Singapore, in 1963. Chow (Tony Leung Chiu-Wai), who has left Hong Kong and has left behind his seemingly unrequited love for Mrs 
Chan (Maggie Cheung Man-Yuk), works at the same newspaper as his friend Ah Ping (Ping Lam Siu). The table is part of the run-of-the-mill setting for the friends' dining out after office hours (ML 01:20:0701:21:20). Chow tells Ping a strange legend of yore about how people used to obliterate the memory of secrets they, like Chow now, would not share. For a while, the camera merely records their eating and conversation from a relatively low angle, showing their backs. Soon, however, it rises to a high angle and pulls back to offer a not unobstructed view, from the opposite side, of the plates on their table (01:21:0001:21:15). Not so much menu diversity as the diners' loneliness despite eating food together does the camera suggest: seated opposite one another, the two men unable to share one secret may feel divided by the table qua signifier of opposed personalities.

A similar scene, featuring Mrs Chan and Mr Chow, involves a classy Hong Kong restaurant ( $M L$ 00:35:01-00:35:49). For the two Shanghainese listening to Nat King Cole's Aquellos Ojos Verdes, the table with its western cutlery and the food they order configure a doubly alienating décor, ethnic and civilisational. The reason for eating out together - to check sore intuitions about their respective spouses' infidelity - causes further alienation. When Chow invited his fellow tenant to dinner to confide his fears that his wife was having an affair with Mr Chan, he would not have foreseen that Mrs Chan knew it too. He needed a physical table to lay his infidelity suspicions on (00:27:5500:30:45). Nor would Chow have envisaged her response on another occasion at the same (or a similar) table: that Mrs Chan would ask him to order for her what his wife preferred, for her to be in her husband's lover's shoes and feel the taste of adulterous attraction (00:33:1300:35:00). Seated opposite one another, the man and the woman feel rather united by the table in their common grief, divided as their respective matrimonial relations have become. In fact, united in division, this time their own from their society, Mrs Chan and Chow will also feel at various tables - such as the bedside table in his rented room at the Koos (00:45:26-00:47:37) or the dressing table in the hotel room where Chow moves (00:55:56-00:57:40). Used for writing, eating and/or singing, when 
the two platonic lovers work together on martial-arts stories for newspapers, such tables provide a convention-(quasi-)free orientation.

Women and/at the Table

In Greenaway, visually impeccable homogenisation around Spica's dining table (CTWL 01:02:23-01:02:27), hence a smooth top-down working of power, never genuinely obtains. The outraged wife resists her abusive husband both covertly and overtly. Unbeknownst to Spica, Georgina takes a lover right in the restaurant (00:22:18-00:27:39, 01:09:51-01:10:00) and flirts with him under her husband's nose (00:15:35-00:16:54, 00:21:01$00: 21: 32$ ). She defies Spica both publicly by describing her gynaecological condition to Michael, at the table, to her husband's mounting anger (00:53:53-00:54:29), and privately by lying to Spica, in the kitchen, about her gynaecologist (00:56:28-00:56:43). Every act of defiance gets sorely punished.

Notwithstanding, unless they become the object of Spica's violence, women are but "exotic" décor at the table. My argument rests on an aesthetic detail: Spica's dining table (like his attire) mirrors a baroque genre painting whose wall-size replica appositely towers the Le Hollandais. As its title announces, Frans Hals's The Banquet of the Officers of the St George Militia Company (1616) features men banqueting. Contrariwise, Spica's daily banquets welcome women: the gangster needs to demonstrate his kyriarchal power over men and women alike. Yet as blown-up replica of the original painting (in the Frans Hals Museum, Haarlem), Greenaway's Frans Hals undermines Spica's claim that his dining table is the exclusive seat of patriarchal power. If the group portrait celebrating men's civic power can be reproduced to grace a restaurant wall (both indoors and outdoors), thus altering its significance, so can power itself, as a relationship enacted amongst individuals, be wrested from its self-styled legitimate yielders to be re-produced, disseminated and liquefied. Georgina works, therefore, as the very principle of power disruption: the wife turns the tables on Spica when she leaves the dining table which he presides over to go to the kitchen and find amorous comfort amidst the shelves or on the tables of the pantry. 
Wong's tables signify a far different type of power. One particular scene in $M L$ indicates the kitchen table - and the kitchen - as the set for the drama of custodial culture (Ozick 443-9) affecting women: kyriarchy is securely in place as long as members of the oppressed group patrol its boundaries to discourage rebellion. For convenience, I delimit the scene to start when, in the Suens' hallway, Mrs Suen, the elderly landlady, admonishes her young tenant to change her lifestyle and persuade her husband to stay at home more ( $M L$ 01:01:12-01:01:45); it ends with a glimpse of Mrs Chan watching the neighbours playing mah-jong after dinner (01:03:02). Not only has the early chiding determined Mrs Chan to cook for herself (or join the family dinners) rather than go out on her own (actually to work with Chow on his stories), but it shows the kitchen's symbolic role in the domestic economy of the film (as of actual lives). After being lectured, Mrs Chan weeps on spotting the kitchen - shown synecdochically as a soup pot on the foremost table - adjoining her room (01:01:56-01:02:09). Arguably, the scene renders the kitchen the signifier of "right" domestic qua matrimonial relationships: it reminds the wife of her domestic duties as the fuel of wholesome matrimony. The social myth is one shared East and West. Not only does it tie women to certain patriarchally prescribed domestic roles and moral duties, but it also transcodes the former as the ingredient of happiness: a woman should be the Hestia of her marriage even to an unfaithful husband. Quite tellingly, the chiding suggests Mrs Suen suspects Mrs Chan of infidelity and dissoluteness due to her long absence from home in the evenings, though not her husband too for his systematic absence from home, motivated as business trips to Japan. Subsequently, Mrs Chan busies herself in the kitchen, ready to cook, but abandons her plans when the amah (Tsi-Ang Chin), the Suens' congenial female servant, ${ }^{13}$ who is invisibly (yet audibly) chopping vegetables, invites Mrs Chan to dine with the family (01:02:41-01:03:01). With the invitation, middle-class decorum - who does what in the kitchen - has been re-established too.

The kitchen table, whether at home or in the noodle stall, never earns the camera's undivided attention. However, the case begs philosophical and intersectional scrutiny. Mrs Chan enters Mrs Suen's kitchen occasionally, e.g. for a cup of tea (ML 00:36:21-00:36:45) or for 
the thermos flask (00:07:57-00:08:03) to go to the noodle stall. Under the circumstances, the quasi-invisible kitchen table qualifies, I submit, as an unobserved object - whose existence, Bertrand Russell would argue, can be inferred but is not seen, and correlates with an unoccupied perspective. According to Ann Banfield, Russell's paradoxical position on unobserved objects $(48-50,67-78)$ is a form of epistemological agnosticism (48) which repudiates the traditional model of knowledge through direct perception (49). ${ }^{14}$ Simplifying, for Russell, in Mysticism and Logic (1917; henceforth $M \& L$ ), sensibilia as physical objects external to the mind exist even in the absence of any percipient (viz., observer); if present, the percipient perceives the sense-data (external to the mind) caused by the sensibilia and may also become aware of the fact of perception (i.e., sensation) ( $M \& L$ 145-58). Russell names perspective "a private world without assuming a percipient" ( $M \& L 160)$. Defined in relation to "observation's purely structural position" (Banfield 72), the perspective is therefore predetermined, hence "the possibility of an unoccupied privacy" (72), i.e., an unoccupied perspective "from which the mind is momentarily absent" (183). ${ }^{15}$

Wong may have been completely unaware of Russell's epistemic position on unobserved objects such as the table. Notwithstanding, Wong's camera work visualises Russell's theory, if with an explicit aesthetic - and implicit social - agenda. To begin with, never does the camera enter the kitchen, as it is symbolically a polluted, or abject, space and (or rather because) it is socially the devalued space of domestic work. The camera may partially follow the amah, moving from table to stove whilst cooking (ML 00:07:52-00:08:22), or show an unattended kettle boiling on the stove and pans and pots piled on the foremost table (00:11:22) adjacent to the cupboard. However, it does so synecdochically, by displaying cooking steam and kitchen paraphernalia, and always from the safe "bourgeois" distance of the hallway. ${ }^{16}$ The kitchen-centred set seems to function primarily as a signifier of domesticity (00:04:0200:04:18) which furnishes the backdrop for friendly intercourse between Mrs Chan and either Mrs Suen (00:04:29-00:04:32, 00:08:03-00:08:14, $00: 39: 37-00: 40: 11)$ or the amah (00:07:55-00:07:59, 00:36:21-00:36:39). $M L$ also suggests, in the kitchen and by leaning - literally or 
metaphorically - on the kitchen table, interrupted social intercourse, such as in the scene preceding Chow's departure to Singapore (01:14:0301:15:29). In the Suens' kitchen, Mrs Chan sits, glass in hand, listening to the song which her husband has dedicated to her on her birthday, aired on the radio; in the Koos' kitchen, Chow sits lonely and melancholy, rice cooker in hand. In the former kitchen, a kettle on the stove issues steam (01:14:22-01:14:34): domestic bliss (on the woman's birthday) literally boils down to being in the kitchen to cook (for herself, now, as her unfaithful husband is in Japan). In the scene, Mrs Chan's mood renders the kitchen implements one case of philosophically unobserved objects and hers an unoccupied perspective.

By contrast, the street stall selling noodle soup is a large basement kitchen whose tables can implicitly accommodate cooking (never shown) and selling food (00:15:26-00:15:30), as well as eating on the premises, as Chow (00:16:38-00:16:54) and other customers (00:15:12-00:15:38), but not Mrs Chan, do. Before long, Mrs Chan and Chow will intersect on the staircase of the stall (00:16:58-00:17:07, 00:24:37-00:24:64). However, when the two start dining out together, but especially when they eat takeaway food in Chow's room, the street stall fades out of visual existence: socially rather than philosophically, the noodle stall, tables and all, becomes an unobserved object.

Wong's film recalls the bourgeois hierarchy of tables in $T L$. Woolf never mentions the kitchen table in relation to cooking, but only the dining table failing to fully catalyse the dinner party. Likewise, $M L$ never shows either domestic cooking proper or public cooking, but lingers on the dining table as a catalyst for sociality even after the meal is over: the Suens and Koos play mah-jong ( $M L$ 00:46:19-00:46:33, 01:03:0201:03:43). Precisely against such interaction do the Chans (and the Chows) reunite on one of Chan's earliest returns from Japan (00:05:0300:05:56) or does Mrs Chan contemplate her life as a cheated wife who cannot even pursue a platonic friendship with Chow for fear of gossip (01:03:02-01:04:46).

In $T L$, the dining table furnishes Mrs Ramsay the mental trigger for a sober reviewing of her life. She finally acknowledges her alienation 
from everything she has relied on, whilst directing the guests to sit at the table and serving them the soup:

But what have I done with my life? thought Mrs. Ramsay, taking her place at the head of the table, and looking at all the plates making white circles on it. "William, sit by me," she said. "Lily," she said, wearily, "over there." They had that - Paul Rayley and Minta Doyle - she, only this - an infinitely long table and plates and knives. At the far end, was her husband, sitting down, all in a heap, frowning.... She could not understand how she had ever felt any emotion or any affection for him. She had a sense of being past everything, through everything, out of everything, as she helped the soup.... It's all come to an end, she thought, while they came in one after another, Charles Tansley - "Sit there, please," she said - Augustus Carmichael - and sat down. And meanwhile she waited, passively, for someone to answer her, for something to happen. But this is not a thing, she thought, ladling out soup, that one says.

Raising her eyebrows at the discrepancy - that was what she was thinking, this was what she was doing - ladling out soup - she felt, more and more strongly, outside that eddy; or as if a shade had fallen, and, robbed of colour, she saw things truly.... Nothing seemed to have merged. They all sat separate. And the whole of the effort of merging and flowing and creating rested on her. Again she felt, as a fact without hostility, the sterility of men, for if she did not do it nobody would do it....

What damned rot they talk, thought Charles Tansley, laying down his spoon precisely in the middle of his plate, which he had swept clean, as if, Lily thought (he sat opposite to her with his back to the window precisely in the middle of the view), he were determined to make sure of his meals. (Woolf 240, 241, emphasis added)

The truth that stares Mrs Ramsay in the face, thanks to the dining table, is her fruitless efforts to connect people: "They all sat separate" (Woolf 240). ${ }^{17}$ Modernist painter Lily Briscoe too watches, as if from a theatre seat, the inherent separation around this table (241).

Yet the two women differ. Spectatorship notwithstanding, Lily appropriates the dining table mentally to visualise how to improve her abstract painting of Mrs Ramsay with her son James. Accordingly, Lily repurposes the salt cellar as an aide-memoire appropriately placed on the patterned tablecloth (covering the table), metaphoric for her canvas (mounted on the easel): 
Then her eye caught the salt cellar, which she had placed there to remind her, and she remembered that next morning she would move the tree further towards the middle....

She had been looking at the table-cloth, and it had flashed upon her that she would move the tree to the middle, and need never marry anybody, and she had felt an enormous exultation. (Woolf 247, 310)

Privately, then, the dining table becomes, for Lily, unlike for Mrs Ramsay, Bankes or Tansley, a prop for memory, or rather furnishes utensil-props capable both of capturing and fixing mnemonically the elusive aesthetic vision (Woolf 241, 242, 247) ${ }^{18}$ and of conveying Lily's determination to bypass social strictures (310). Lily partially withdraws within the tablecloth/canvas from the dinner party's chatter, lest it blur her vision. The separation, rather than reunion, at the dinner party and around the dining table, as sensed by Mrs Ramsay (240), works in Lily's case in aesthetic terms - professional, as for men - yet whose ambit depends on the woman's social emancipation, not mere psychological absence from the site of polite socialisation.

The dining table serves, in Woolf, yet another purpose: to intimate the aestheticisation of everyday life and at the same time mount a feminist critique of the masculine gaze. I cannot repeat here my demonstration regarding the pièce de résistance of the dinner party: Rose's dish of fruit (Ciobanu 149-53). Suffice it to note that Mrs Ramsay walks the tight rope between her usual female selflessness and modesty, intertwined with admiration for men as thinkers, and a criticism of men as selfish, which both her efforts for a successful dinner party and her jealous guarding of the fruit dish demonstrate aplenty. On the other hand, she is a woman of her (middle-)class who rarely considers her servants' efforts to make the party work at all. She acknowledges her daughter's contribution with aesthetic panache (Woolf 250, 259); Mildred the cook's but dryly. ${ }^{19}$

\section{Men, Women and Woolf's Wayward Tables}

The dinner party in $T L$, I submit, upends aesthetically the novel's concern with knowledge (which renders the kitchen table an abstract philosophical analogon). In the early, epistemic scene, Lily enquires about the philosophical pursuits of Mr Ramsay, to learn from Andrew that "his 
father's books were about 'Subject and object and the nature of reality'" (Woolf 196). In response to her bewilderment at the formulation, Andrew instructs Lily to deploy a mundane image for the nature of reality: “"Think of a kitchen table then,' he told her, 'when you're not there"' (196). Explicitly divorced from its physical environs, the kitchen table has to be considered on its own, yet not for its material or socially related merits, but as the philosophical prop for "a non-psychological knowledge whose subject matter is irreducible to any subject's mental state" (Banfield 48). ${ }^{20}$ Andrew tacitly adopts Russell's philosophy of unobserved objects and unoccupied perspectives: he advises Lily to empty her mind's eye of herself as perceiving subject of reality - an orientation radically opposed to Husserl's phenomenology. Ironically, Andrew's analogy also invites (the) woman out of the kitchen for philosophy to colonise the ultimate female stronghold (as decreed by patriarchy)! As in philosophy, in $T L$ reality can be represented by - viz., reduced to - a (kitchen) table. Nonetheless, such transcending of immanence, of materiality, of one's embodied self to attain angelic decorporealisation for perfectly abstract, Cartesian thought, is mere abstruse jargon to Lily, as to most non-fictional women in the early twentieth century.

Banfield comes close to suggesting the conflicting gendered perspectives on the kitchen table as philosophical analogon:

For the table Lily imagines, upon which the philosopher grounds his work and which the painter paints ... is a "scrubbed kitchen table" seemingly "laid bare by years of muscular integrity," recalling "one of those scrubbed board tables" [Woolf 196] stripped by the likes of Mrs. McNab [the Ramsays' cook]. Nonetheless, it is Mr. Ramsay's philosophical investigations which are by implication credited for this integrity in Lily Briscoe's mind. (50, emphasis added)

I beg to differ as regards Lily's unequivocal crediting of philosophical labour as the one responsible for the integrity of the kitchen table image. On the one hand, the artistically mature Lily of Part III muses that the "angular essences" (Woolf 196) of the philosophical kitchen table appear impressed on Mr Ramsay's face (294). Lily's free indirect thought allows for little or no irony: 
But what a face, she thought, immediately finding the sympathy which she had not been asked to give troubling her for expression. What had made it like that? Thinking, night after night, she supposed - about the reality of kitchen tables, she added, remembering the symbol which in her vagueness as to what Mr. Ramsay did think about Andrew had given her... The kitchen table was something visionary, austere; something bare, hard, not ornamental. There was no colour to it; it was all edges and angles; it was uncompromisingly plain. But Mr. Ramsay kept always his eyes fixed upon it, never allowed himself to be distracted or deluded, until his face became worn too and ascetic.... Then, she recalled..., worries had fretted it - not so nobly. He must have had his doubts about that table, she supposed; whether the table was a real table; whether it was worth the time he gave to it; whether he was able after all to find it. He had had doubts, she felt, or he would have asked less of people. (Woolf 294-5)

On the other hand, subsequent to her philosophical induction by Andrew, Lily muses, in Part I: "Naturally, if one's days were passed in this seeing of angular essences, this reducing of lovely evenings, with all their flamingo clouds and blue and silver to a white deal four-legged table (and it was a mark of the finest minds to do so), naturally one could not be judged like an ordinary person" (Woolf 196). We can sense here Woolf's (not just Lily's) feminist irony. Eliding the "white deal four-legged table" (Woolf 196) with the nature of reality, or at least with an object of philosophical enquiry - as Russell (Problems of Philosophy, 1-2), Hume and Wittgenstein do (Banfield 43, 66) - is pre-eminently natural. Sustenance, now defamiliarised through sublimation and reification, is the disavowed core to which "the finest minds" reduce (Woolf 196) reality's multifarious nature to posit unobserved objects and thus shift epistemic paradigms out of most people's, not just women's, mental grip - yet also obliterate the domestic work economy the table participates in!

More than Mrs Ramsay treasures and guards aesthetically Rose's dish of fruit, Andrew as a self-appointed custodian of the kitchen table of philosophy tries to secure correct handling of the mental prop. His objects of silent concern are those whom patriarchy deems epistemically inapt: women - women attached to ordinary kitchen tables.

His kitchen-table argument by analogy renders Andrew himself a philosopher. Philosophical metadiscourse repudiates philosophical thought in images, yet allows two major exceptions (le Doeuff 6-7). Andrew's teaching deploys the "downstream" variant, whose homely 
metaphors replacing abstract concepts adjust philosophical discourse for non-philosopher audiences. However, this condescending exception downplays another usage, intended for in-group initiation. In their metaepistemic discourse on how to approach philosophy, various philosophers also use imagery, often appropriating the denigrated housework in the metaphor of sweeping clean one's mind before engaging oneself philosophically (Descartes 12; Bordo 627; cf. Rooney 80; Thompson 49-50). Repurposed metaphorically as the philosopher's degree zero, house cleaning - coterminous with the feminised subaltern other shows, I argue, the philosophers' metaphorical colonisation of the space of the hearth and family, only to repudiate this space's activities as garbage.

Nonetheless, Lily is no passive listener, nor, at least thanks to her middle-class privilege, a woman definitionally attached to the kitchen table. Woolf's feminist mimicry of philosophical arguments, with their implicit vindication of male positions of epistemic (or political) authority, transpires in Lily's mental follow-up exercise:

So now she always saw, when she thought of Mr Ramsay's work, a scrubbed kitchen table. It lodged now in the fork of a pear tree, for they had reached the orchard. And with a painful effort of concentration, she focused her mind, not upon the silver-bossed bark of the tree, or upon its fish-shaped leaves, but upon a phantom kitchen table, one of those scrubbed board tables, grained and knotted, whose virtue seems to have been laid bare by years of muscular integrity, which stuck there, its four legs in air. (Woolf 196)

Woolf's young middle-class white woman unpacks phenomenologically metaphysics and epistemology, traditionally the province of upper- or upper-middle-class white men. Freed by Lily from its ties with the kitchen, the kitchen table - one typically used in the preparation of food by the subaltern (whether housewife or domestics) - levitates philosophically with subjective nonchalance, albeit not in Russell's unobserved terms. Lily's upturned kitchen table shifts its elusive location as a function of the novice philosopher's: Lily now in the orchard, the "phantom kitchen table" 21 haunting her mind appears smugly "lodged ... in the fork of a pear tree" (Woolf 196), disingenuously freed from middle- 
class (sexual) decorum too. Lily has faithfully, if creatively, followed Andrew's instructions to contemplate the kitchen table qua philosophical analogon when she is not in the kitchen! Lily's kitchen table thwarts not only (the) gravity (of metaphysics), but also the masculine grip on the elusive nature of reality.

\section{Conclusions}

My analysis of the tables mentioned or shown in Woolf's $T L$, Greenaway's CTWL and Wong's $M L$ suggests that thinking philosophically and intersectionally with the table may yield a complex aesthetic and social picture. Whilst the table is present explicitly philosophically only in Woolf (in Lily's exchange with Andrew), implicitly it also features in Wong in connection with Russell's theory of unobserved objects, yet, as I have argued, in the latter case an intersectional reading can put the philosophical one in perspective. On either reading and in all three works, the table is embedded in discursive practices of power and signifies power relations, however unstable the latter may appear in Woolf or Greenaway at times. Intersectionally, the table - whether the dining or kitchen table - often conceals social issues having to do with the middle-class background of the protagonists or, in Greenaway, aspiration to be regarded as a socialite. Not only can food be prepared or consumed at the table, but so can patriarchal notions of "natural" gender identity and roles or, less generally, the abstract ideas of a highly speculative and highly androcentric discipline. Philosophy, nonetheless, has not shied away from colonising - metaphorically or otherwise - that part of human life deemed unworthy of speculating about: sustenance. ${ }^{22}$

To return to the work I started with, in $T L$ the table appears both overdetermined and dematerialised. Just as the kitchen table is deployed as the signifier of a second-degree sign, i.e., the nature of reality as addressed by philosophy, so does the dining table with its utensils become Lily's aide-memoire through metaphorical transcoding into an easel for the painter's canvas. Yet, precisely through yielding to such signifying processes, the two kinds of table also lose their materiality: they 
participate in the symbolic realm of social signification - symbolic in a Lacanian sense - and thereby their ordinary denotative and connotative spectrum fades away. Not the labour of love (itself a patriarchal myth) or of necessity (whether the wife's or the domestic's) will the kitchen table signify, but the speculative work of an exclusivist male caste; not daily drudgery, socially symbolised as immanent and feminised, but intellective quest, the work of reason, symbolised as transcendent and masculinised sublime. Rather than simply a part of the set, the square table is a piece of physical and mental furniture circumscribed by a vicious social circle many flesh-and-blood women (including fe/male domestics) have choked on.

\section{Notes:}

${ }^{1}$ This investigation complements that undertaken in my conference paper "Not Just Eating, but Consuming: Food and Cooks in To the Lighthouse, The Cook, the Thief, His Wife and Her Lover and In the Mood for Love" (Lucian Blaga University of Sibiu, Nov. 2019), centred on cooks, food and acts of cooking or eating.

${ }^{2}$ Kyriarchy, Elisabeth Schüssler Fiorenza's (11-14) coinage, names the implicit hierarchy within patriarchy.

${ }^{3}$ In intersectionality theory the term denotes the collusion of multiple forms of domination, such as the interlocking systems of domination of sexism, racism and classism (hooks 19-27, 170-2, 175-6).

${ }^{4}$ I cannot discuss here Husserl's skewered sense of the "natural" in his two phrases (Husserl 54), once the philosopher contemplates "the physical things in front of me furnished not only with merely material determinations but also with value-characteristics, as beautiful and ugly, pleasant and unpleasant, agreeable and disagreeable, and the like" (53, emphasis added).

5 Teresa de Lauretis's spelling (240) underpins her cogent analysis of the gendered production of the subject position (whether in politics or epistemology) as male and the object position as female or feminised.

6 See Kerner and Chou (1-3) on the three theorists' interpretation of commensality.

${ }^{7}$ The true stakes were hardly philosophical, though, as The History of Sexuality 2 indicates: the ancient Greek philosophers aimed to legitimise an erotic practice at odds with the needs of the polis (viz., reproduction within wedlock) by celebrating erotic moderation and abstinence as the philosopher's virtues (Foucault, esp. 35-7, 86-98, 143-51).

${ }^{8}$ CTWL shows the story of a gangster, Albert Spica, who commandeers the Le Hollandais restaurant, where he dines every evening with his abused wife Georgina and his associates. Georgina starts a love affair with Michael, a keen 
reader of history books who owns a book depository. When the adultery is revealed to him, Spica executes Michael; Georgina revenges by coercing her husband to eat from her lover's roasted body. Richard, the Le Hollandais chef, sympathises with Georgina, supports her adultery and eventually cooks Michael's body for Spica.

9 Only when Spica is in the kitchen does hierarchy become visible (CTWL 00:34:22-00:35:22).

${ }^{10}$ Richard's duck plucking generates theatrical snow-flakes in the kitchen; the power cut (through short-circuiting the system when the restaurant sign is lit) requires candle lighting like in church, just as Pup's religious chanting evokes a church. In a short space of time (roughly two minutes), the kitchen demonstrates its versatility as a function of what is actually focused on.

${ }^{11}$ I elaborate on theatricality in my conference paper ("Not Just Eating, but Consuming").

${ }^{12} M L$ shows the platonic love between two neighbouring lodgers, Mrs Chan, a secretary at a shipping company, and Mr Chow, a journalist, after realising their respective spouses have a love affair with each other.

13 "Amah" - a common noun for Chinese (or more infrequently foreign) live-in servants (i.e., paid domestic workers) - is used in the Chinese spoken in Hong Kong, Singapore and Malaysia (but not in China as well) either by natives or by English colonists (Constable 52-62). Traditionally, the amah, whether a pre-1945 immigrant or post-1945 refugee, strictly adheres to "the classical standards of the master-servant relationship" of full subservience and loyalty (Sankar, qtd. in Constable 54).

14 Russell's is an anti-idealist - anti-Berkeleyan - proposition which "externaliz[es] perception from the subject" and thus "approaches "the abolition of the subject," to the effect that "[w] hatever exists is perceptible, but not necessarily perceived by anyone" (Banfield 48; see also 67-78). Analysing perception, Russell argues, in The Problems of Philosophy (1912; henceforth PP), the difference between appearances offered by sense-data (as furnished by perceiving a table from various angles or in different lights) and the physical object (the table) which causes the sense-data and whose intrinsic nature cannot be known, but only inferred through instinctive belief (PP 1-51).

15 The early version of perspective, named private world, concerns the observer who perceives sense-data (Russell, $M \& L$ 158-9).

16 Indeed, the film frames most indoor intercourse such as to distance the characters aesthetically (and/or socially) from the spectators.

${ }^{17}$ Only late in the evening will Mrs Ramsay's vision of a divided table dispel, replaced by that of a genre painting (Ciobanu 154), though no commensal circle: "Now all the candles were lit, and the faces on both sides of the table were brought nearer by the candle-light, and composed, as they had not been in the twilight, into a party round a table...." (Woolf 250, emphasis added). Candle light(ing) creates the theatrical-painterly trompe-l'oeil that erases differences.

${ }^{18}$ I address elsewhere (Ciobanu 157-60) Lily's own "philosophical"-aesthetic reductionism as a modernist painter. The mnemonic props furnished by the dining 
table enable Lily to move mentally from tree (represented in the early painting) via salt cellar (placed on the dining table) to line (drawn in the final painting) so as to capture her Mondrianesque vision of the Madonna-with-the-Child portrait of Mrs Ramsay.

19 "[T]hey were having Mildred's masterpiece - Boeuf en Daube" (Woolf 238).

${ }^{20}$ By using here the kitchen table (as in The Voyage Out), and especially by calling it a table, as elsewhere in her novels (The Waves; Night and Day; Jacob's Room; The Years), Woolf "explicitly aligns herself" with the philosophical tradition which had used the table as the "paradigmatic object of knowledge" (Banfield 66) and "signals the entry of the problem of knowledge into the novels" (67).

21 "Phantom" because philosophically an unobserved object (Banfield 55): "the vanished observer leaves in his [sic] wake not nothing but a world of phantom "solid objects"” (49).

${ }^{22}$ Traditionally, though, its practitioners have speculated in sustenance-related processes through the employment of domestics (or slaves).

\section{Works Cited}

Ahmed, Sara. "A Phenomenology of Whiteness." Feminist Theory 8.2 (2007): $149-68$.

Banfield, Ann. The Phantom Table: Woolf, Fry, Russell and the Epistemology of Modernism. Cambridge: Cambridge UP, 2000.

Bordo, Susan. "Feminist Skepticism and the 'Maleness' of Philosophy." Journal of Philosophy 85.11 (1988): 619-29.

Ciobanu, Estella Antoaneta. "Food for Thought: Of Tables, Art and Women in Virginia Woolf's To the Lighthouse." American, British and Canadian Studies 29.1 (2017): 147-68.

Constable, Nicole. Maid to Order in Hong Kong: Stories of Migrant Workers. $2^{\text {nd }}$ ed. Ithaca: Cornell UP, 2007.

The Cook, the Thief, His Wife and Her Lover. Directed and written by Peter Greenaway. With Richard Bohringer, Michael Gambon, Helen Mirren and Alan Howard. Allarts, Elsevier-Vendex Film Beheer, 1989. DVD.

de Lauretis, Teresa. "The Violence of Rhetoric: Considerations on Representation and Gender." The Violence of Representation: Literature and the History of Violence. Ed. Nancy Armstrong and Leonard Tennenhouse. London: Routledge, 1989. 239-58.

Descartes, René. The Philosophical Writings of Descartes II: Meditations on First Philosophy. Trans. John Cottingham et al. New York: Cambridge UP, 1984.

Foucault, Michel. The History of Sexuality II: The Use of Pleasure. Trans. Robert Hurley. New York: Vintage, 1990.

hooks, bell. Talking Back: Thinking Feminist, Thinking Black. Cambridge, CA: South End P, 1989. 
Husserl, Edmund. Collected Works II: Ideas Pertaining to a Pure Phenomenology and to a Phenomenological Philosophy. First Book: General Introduction to a Pure Phenomenology. Trans. F. Kersten. The Hague: Martinus Nijhoff, 1983.

In the Mood for Love. Directed, written, and produced by Wong Kar-Wai. With Tony Leung Chiu-Wai and Maggie Cheung Man-Yuk. Jet Tone Films , 2000. DVD.

Kerner, Susanne, and Cynthia Chou. "Introduction." Commensality: From Everyday Food to Feast. Ed. Susanne Kerner, Cynthia Chou, and Morten Warmind. London: Bloomsbury, 2015. 1-10.

Le Doeuff, Michèle. The Philosophical Imaginary. Trans. Colin Gordon. London: Continuum, 2002.

Ozick, Cynthia. "Women and Creativity: The Demise of the Dancing Dog" (1969). Rpt. in Woman in Sexist Society: Studies in Power and Powerlessness. Ed. Vivian Gornick and Barbara K. Moran. New York: Basic, 1971. 431-51.

Rooney, Phyllis. "Gendered Reason: Sex Metaphor and Conceptions of Reason." Hypatia 6.2 (1991): 77-103.

Russell, Bertrand. Mysticism and Logic and Other Essays. London: Allen and Unwin, 1917.

---. The Problems of Philosophy. 1912. Introduction by John Skorupski. $2^{\text {nd }}$ ed. Oxford: Oxford UP, 1998.

Schüssler Fiorenza, Elisabeth. "Introduction." Democratizing Biblical Studies: Toward an Emancipatory Educational Space. Louisville: Westminster John Knox P, 2009. 1-21.

"Table." Oxford Dictionary online. Web. 12 Jan. 2019.

Thompson, Patricia J. "Dismantling the Master's House: A Hestian-Hermean Deconstruction of Classic Texts." Hypatia 9.3 (1994): 38-56.

Woolf, Virginia. Collected Novels of Virginia Woolf: Mrs. Dalloway, To the Lighthouse, The Waves. Ed. Stella McNichol. London: Macmillan, 1992. 